\title{
Research Article: Comparative economic analysis of chickpea cultivation in mechanized and non-mechanized farms of India
}

\section{口.C. SHILPA, S.M. MUNDINAMANI AND SHREESHAIL RUDRAPUR}

Article Chronicle : Received : 10.07.2017;

Accepted : 25.07.2017

KEY Words: Mechanized, Nonmechanized, Herbicide resistant
SUMMARY : The present study examinesthe extent of mechanization, cost and returns of manual and mechanical harvesting and threshing of chickpea.A multistage sampling procedure was adopted for the selection of study area, sample farmers and machine owners. The sample size for the study was 90 comprised of 60 chickpea growing farmers and 30 machine owners. Farm budgeting and tabular analysis was used to analyze the data. The data pertained to the agriculture year 2013-14. About 70 per cent of the sample farmers harvested chickpea engaging human labour and threshed it with machine and remaining 30 per cent of the sample farmers have used machine both for harvesting and threshing.On an average both states together, total human labour, bullock labour and machine hours utilized in the study areas was found to be 33.66 man days, 5.39 pair days and 4.69 hours, respectively. Although the quantities of inputs used were less per acre, the total expenditure incurred on these inputs was more in case of Maharashtra (Rs.13,443.88/ha) when compared to Madhya Pradesh (Rs.12,133.73/ha). The benefit-cost ratio indicated that chickpea cultivation was found to be economically viable for the farmers in the study states. The net profit of mechanical harvesting and threshing over manual harvesting and machine threshing was Rs. 2613 and Rs.3044in Maharashtra and Madhya Pradesh, respectively.

How to cite this article : Shilpa, P.C., Mundinamani, S.M. and Rudrapur, Shreeshail (2017). Comparative economic analysis of chickpea cultivation in mechanized and non-mechanized farms of India. Agric. Update, 12(TECHSEAR-3) : 770-776; DOI: 10.15740/HAS/AU/12.TECHSEAR(3)2017/770-776.
Author for correspondence :

\section{P.C.SHILPA}

Department of Agriculture Economics, University of Agricultural Sciences, DHARWAD (KARNATAKA) INDIA

Email : agrichoutishilpa @ gmail.com

See end of the article for authors' affiliations 